\title{
Accountability, Governance and Performance in UK charities
}

\section{Giulia Bellante}

Department of Economic Studies,

G. D’Annunzio University,

Pescara, Italy

Email: giulia.bellante@unich.it

\section{Laura Berardi*}

Department of Economic Studies,

G. D’Annunzio University,

Pescara, Italy

Email: 1.berardi@unich.it

*Corresponding author

\section{Silke Machold}

Management Research Centre,

University of Wolverhampton Business School,

Wolverhampton, United Kingdom

Email: S.Machold@wlv.ac.uk

\section{Eugenia Nissi}

Department of Economic Studies,

G. D’Annunzio University,

Pescara, Italy

Email: nissi@unich.it

*Corresponding author

\section{Michele A. Rea}

Department of Economic Studies,

G. D’Annunzio University,

Pescara, Italy

Email: $\underline{\text { m.rea@unich.it }}$

\begin{abstract}
The aim of this paper is to analyse the relationship between governance characteristics of a sample of 200 UK non-profit organisations (NPOs) and their performance, considered as their ability to collect financial resources. Using a regression analysis, we verify strong positive relationships between the NPOs' financial performance and CEO duality and board size. Further analyses show that if the charities increase their level of accountability through the use of additional voluntary disclosure mechanisms and tools such as the use of social networks, these relationships are confirmed. The results of our research have implications for policy makers that seek to strengthen
\end{abstract}


Bellante G. et al.

governance of NPOs, and for boards and managers of NPOs who wish to develop their organisations' performance.

Keywords: Nonprofit, Governance, Accountability; CEO; Board; Charities.

Reference to this paper should be made as follows: Bellante, G., Berardi, L., Machold, S., Nissi, E., and Rea, M.A. (2016) 'Accountability, Governance and Performance in UK charities', Int. J. Business Performance Management,

Biographical notes: Giulia Bellante is $\mathrm{PhD}$ Student in Business, Institutions, Markets at the Department of Economic Studies of the G. D'Annunzio University. Her research interests are in Governance, Accountability and Management of nonprofit organisations. During her $\mathrm{PhD}$ she is studying these topics in order to compare data and results from different countries, such as France, Canada, UK, Italy, USA and Norway.

Laura Beradi is Professor of Business Administration and Accounting at the Department of Economic Studies of the G. D'Annunzio University. She is International Fellow in Philanthropy of the Johns Hopkins Center for Civil Society Studies of Baltimore (USA). Her research interests are in governance, accounting and management of nonprofit organisations. She also teaches on the topics of business administration, financial and management accounting.

Silke Machold is Professor of Corporate Governance at the University of Wolverhampton Business School, where she also serves as the Head of the Management Research Centre. She has also Vice President (Governance) at the European Academy of Management. Her research interests are in board processes and behaviors and feminist perspectives on corporate governance. She teaches and consults on these topics in the UK and overseas.

Eugenia Nissi is Professor of Statistics at the Department of Economic Studies of the G. D'Annunzio University. She is coordinator of several research projects. Her research interests are in spatial and environmental statistics and in methods for the evaluation of efficiency. She is author of several papers published with national and international editors. She teaches on statistics and time series analysis.

Michele A. Rea is Professor of Business Administration and Accounting at the G. D'Annunzio University. He is coordinator of several research projects on topics of accounting of corporate and nonprofit organizations. He is author of several books and papers published with national and international editors.

This article is a revised and expanded version of a paper entitled "The importance of accountability for the relationship between governance and performance of UK charities" presented at Sidrea International Workshop, UNINT University - Rome, 21-22 April, 2016.

\section{Introduction}

The governance of not-for-profit, charitable organisations has recently attracted much attention from the public, governments and regulatory bodies in the UK and elsewhere. Similar to what has been witnessed in the corporate world, charities have come under 
scrutiny for high levels of executive pay (NCVO, 2014), allegations of mis-management and misconduct (Sussex, 2015), and un-ethical fundraising tactics (Jenkin, 2016). As a result, more and more emphasis has been placed on the role of board of trustees in ensuring that charities are well governed and accountable to their various constituent groups. Yet, despite the proliferation of 'good practice' guidelines for governance (both in the corporate and not-for-profit sector), there remains much theoretical controversy about the nature of optimal governance mechanisms and the empirical evidence base is far from clear-cut (Dalton et al., 1998; Hambrick et al., 2008). In the context of non-profit boards, Hyndman and McDonnell (2009) identified a research agenda to gain a better understanding of governance in charities, which includes questions around the role and composition of boards.

This paper contributes to this emergent research agenda by analysing the relationship between board characteristics of Non-Profit Organisations (NPOs) and their organisational performance in a context characterized by a medium-high level of accountability. We focus on two board characteristics - CEO duality (when the CEO and the board chair are the same person) and board size. CEO duality was chosen because it is a contested concept, both theoretically and empirically. On the one hand, agency theory recommends that the positions of CEO and chair are held by separate individuals in order to limit CEO power and increase board independence (Fama and Jensen, 1983; Rechner and Dalton, 1991), whereas stewardship theory recommends duality in order to empower managers and provide unity of leadership (Donaldson and Davis, 1991). The empirical evidence, however, seems to suggest that whether or not CEO duality affects firm performance is highly context-specific (Boyd, 1995), and as such interesting to explore in the context of NPOs. Similarly when it comes to board size in charities, there are theoretical arguments both for and against large boards and there may be important contingencies affecting this relationship (Hyndman and McDonnell, 2009). The contingency we are particularly interested in is the level of accountability, that is the extent to which the charities chose voluntary disclosure mechanisms above and beyond those mandated by the regulator.

The analysis was conducted on a random sample of 200 UK charities taken from the Charity Commission Register. The United Kingdom, in particular England and Wales, was chosen as the empirical setting for two reasons. First, as already mentioned, governance in the charity sector in the UK, and especially the role of boards, has recently come under much public scrutiny (House of Commons, 2016). This has happened in the context of a national conservative-led economic austerity programme, which has simultaneously increased the demand for services provided by many NPOs and negatively affected revenues of charities (Bridle, 2012). Second, the charity sector in the UK is characterised by a medium-to-high level of regulation and mandatory accountability required for organisations registered with the Charity Commission. As such, there are already mechanisms in place to mitigate the agency problem vis-à-vis information asymmetries and facilitating the monitoring and control role of board members (trustees). The analysis proceeds in two steps. In the first phase we aim to verify how CEO duality and board size are related to organisational performance (assessed by the level of total revenues achieved in the fiscal year) in charities with a medium-high level of mandatory accountability (as required by the Charity Commission). Next, we explore how the relations found in the previous phase change if the charity increases its level of accountability through mechanisms of voluntary disclosure such as 
the publication of information on volunteers, the use of social networks and the declared use of a strategic plan. The paper is structured as follows: in the first part we give a brief overview of the literature on the topic of accountability followed by an examination of the theoretical rationale linking CEO duality and board size to organisational performance. In the second part we explain the hypotheses on the relationships between the governance and accountability variables and organisational performance. The third part explains the methods and the analysis to verify (or reject) the hypotheses, and this is followed by the discussion of the results and the conclusions.

\section{Theoretical background}

\section{Literature review}

The topic of accountability of NPOs is a central theme that many authors have explored and analysed in the past and present literature of non-profit governance (Cavill and Sohail, 2007; Connolly et al., 2013; Schedler, 1999). Non-profit organisations' revenues are based mainly on contributions from government and the general public. These funds, which may be generated through contractual or non-contractual means, are subsequently used to serve group(s) of beneficiaries directly or indirectly. Thus, the ability to create trust and confidence is intrinsic to the nature of NPOs and can be fostered by being accountable to stakeholders (Gibelman and Gelman, 2001). However, there is no single agreed definition of what constitutes "accountability" (Cnaan, 1996). Worth defines accountability as "being required to answer, to take responsibility, for one's actions" (Worth, 2009, p. 115). But he goes on to argue that this concept should not be interpreted as merely following the requirements of the law and that "accountability needs to include more than just avoiding transgressions and exhibiting model behaviour. It may need to encompass demonstrated effectiveness in achieving the purposes for which the non-profit exists. That requires not only that the resources entrusted to the NPO not be misused, but also that they be used to maximum benefit in pursuing the organization's mission" (Worth, 2009, p. 116). Anheier (2005) affirms that "in contrast to businesses, which are ultimately about financial profit, nonprofit governance and management are ultimately about the organization's mission" (Anheier, 2005, p. 226). In that sense, the adoption by NPOs of "social accountability" instruments, such as social and mission reports or the use of social-networks, is as pertinent as the use of standard financial accounting tools in profit-driven organisations.

In examining what is "accountability" and how it is manifested in for-profit and notfor profit organisations, authors have focused on different aspects and levels. Behn et al. (2010) focus on voluntary financial disclosure of US non-profit organizations, developing and testing a model based on several studies on for-profit disclosure. Indeed, even though the goals of non-profit organisations are social in nature, economic and financial efficiency and issues related to control are essential in the non-profit sector too. Keating and Frumkin (2003) examine the financial accountability of non-profit organizations and present seven recommendations to enhance non-profit accounting and reporting, such as "developing active boards and organizations that rely on strategic plans and budgets to improve organizational performance and accountability" (Keating and Frumkin, 2003, p. 11). They further highlight the importance of accounting that goes beyond financial results. Ebrahim (2010), focusing on "the many faces of non-profit accountability", highlights that issues related to accountability involve "deciding both to whom and for 
what" the NPO is accountable. He views accountability as a relational concept that "varies according to the relationships among actors" (Ebrahim, 2010, p.7). In addition, the organisation should be accountable not only in relation to financial results, but also to governance, performance and organisational mission.

In a context of medium-to-high levels of accountability, we aim to analyse how some characteristics of governance of NPOs influence the organisational performance, thus trying to fill the gap found in the literature on the non-profit accountability.

Boards of directors or trustees are considered to be at the apex of an organisation's internal governance system (Fama and Jensen, 1983). As such, they are expected to fulfil two broad roles - to monitor and control management, and to provide advice and strategic direction (Hillman and Dalziel, 2003; Sundaramurthy and Lewis, 2003). Agency theory underpins the board's monitoring and control task since under conditions of separation of ownership and control, and assuming managers (agents) are inclined to pursue actions that are contrary to the interests of principals (shareholders, donors), there is a need for a governance mechanism such as the board to curb self-seeking behaviours and control the actions of the agent (Fama and Jensen, 1983; Hillman and Dalziel, 2003). Whilst boards' involvement in monitoring and control can prevent value-destruction in the organisation, a range of other theories focus more specifically on how boards can create value. Resource dependence theory (Hillman and Dalziel, 2003; Pfeffer and Salancik, 1987), strategic choice theory (Judge and Zeithaml, 1992), stewardship theory (Davis et al., 1997; Sundaramurthy and Lewis, 2003) and stakeholder theory (van Puyvelde et al., 2012; Wang and Dewhirst, 1992) have been drawn upon to explain how boards contribute resources, provide advice and strategic direction, as well as legitimating the organisation in its external environment. The question that scholars have then sought to address is which board characteristics are most likely to influence boards' ability to perform these different roles. We turn to examine two such characteristics CEO duality and board size.

\section{Development of research hypotheses}

Building on the literature review, we adopt a broad conceptualisation of accountability in NPOs as the degree of transparency and openness, as the level of disclosure and answerability (Schedler, 1999) by members who govern the organisation and as a mechanism of governance that can lead the organisation towards better performance. We argue that the relationship between a high level of accountability and the increase in organisational performance can be explained due to reductions in information asymmetry between NPO's management, its board and stakeholders (donors and beneficiaries), which will inter alia strengthen board governance by giving the trustees more information (reports, documents, etc.) to assess the activities of the Top Management Team (TMT) against the mission of the NPO.

\section{1) CEO duality in UK charities}

The question of whether the CEO should also act as the chair of the board in both corporate and non-profit organisations has attracted much scholarly and practitioner interest (Adams et al., 2008; Baliga et al, 1996; Bradshaw et al, 1998; Brickley et al, 1997; Callen et al. 2003; Cornforth, 2001; Dalton and Dalton, 2011; Dalton et al, 1998; Elsayed, 2007; Fama and Jensen, 1983; Miller-Millesen, 2003; Peni, 2014). According to agency theory, the roles should be held by separate individuals in order to avoid CEO 
entrenchment and power (Fama and Jensen, 1983; Lorsch and MacIver, 1989), and to prevent compromising the board's monitoring and control role (the same individual being both the monitor and the one being monitored). In contrast, stewardship and resource dependence theorists advocate duality as it empowers managers and promotes unity of command at the top of the organisational hierarchy (Davis et al., 1997; Donaldson and Davis, 1991), which can lead to speedier and more incisive decision-making in the context of environmental uncertainties (Pfeffer and Salancik, 1978). Yet, the empirical evidence in support of either perspective is rather ambiguous (Krause et al. 2014), and one explanation for this may be found in the insufficient attention to the complementarities of governance mechanisms and contextual variables. Early research by Boyd (1991), for example, showed that CEO duality can be beneficial for firm performance in high complexity environments, since under such conditions strong leadership and decision-speed outweigh the disadvantages of CEO power. More recent research has focused on the notion of governance bundles (Aguilera et al., 2008; Misangyi and Acharya, 2014; Schiehll et al., 2014), and the extent to which different governance mechanisms, such as CEO duality, board independence and external control are complementary or substitute each other.

The context of UK charities may be described as highly complex and uncertain due to changing funding regimes (Bridle, 2012), the delicate line between market and social orientation that charities tread (Seymour et al. 2006), and the intricacies of donor relations and motivations (Hyndman and McDonnell, 2009). Alongside that, as we discussed earlier, the UK charity sector is characterised by a medium-to-high level of accountability, and regulated by an outside body, the UK Charity Commission. The trustees of boards are akin to non-executive directors in the corporate world, and take up the majority of board seats (Grant Thornton, 2013). Under similar ${ }^{1}$ conditions, Misangyi and Acharya (2014) showed that CEO duality can be beneficial for firm performance. Based on these arguments of environmental complexity and supplementarity within governance bundles, we hypothesise that:

H1: CEO duality has a positive impact on the organisational performance (measured as its ability to collect resources, i.e. total revenues), in a context characterized by a medium-high level of accountability.

2) What constitutes an optimal board size?

Scholars have tried to answer this question using a variety of theoretical lenses. The argument from agency scholars is that smaller boards are preferable to large ones as the latter are too unwieldy, may create free-rider problems amongst non-executives and thus generally promote managerial entrenchment (Jensen, 1993; Lipton and Lorsch, 1992). Proponents of resource dependence theory, on the other hand, stress the importance of boards on procuring external resources and mitigating sources of uncertainty in the external environment (Pfeffer and Salancik, 1978). Following that logic, larger boards are advantageous compared to smaller ones, especially in the context of highly complex and uncertain environments. Dalton et al. (1999) in their meta-analysis of board size and firm performance provide empirical support in favour of increased board size. For non-profit

\footnotetext{
${ }^{1}$ Their research was in a corporate setting and measured the market for external control rather than external regulation as we would find in the charity sector.
} 
boards, the resource dependence arguments have been further supplemented by a stakeholder theory logic (Bai, 2013; Cornforth, 2003; Hyndman and McDonnell, 2009) that argues for the need to have a wide stakeholder representation on boards to ensure their voice and enhance organisational legitimacy. Bai (2013), for example, showed that social performance of non-profit hospitals is greater when there are larger boards, whereas the opposite relationship holds when the hospital is for-profit. We therefore propose that:

H2: Increasing board size has a positive impact on the organisational performance (measured as its ability in collecting resources, i.e. total revenues), in a context characterized by a medium-high level of accountability.

3) Mandatory and voluntary accountability in UK charities

As previously stated, the aim of this study is to understand how mechanisms of accountability can indirectly affect the organisational performance, by strengthening or mitigating the relationship between board characteristics (CEO duality and board size) and the ability of the organisation to collect resources. Our analyses are conducted on a sample of 200 registered charities present on the Charity Commission's Register. The choice fell on the United Kingdom, in particular England \& Wales, because it can be considered a good practice example in relation to the regulation and level of mandatory accountability required for organisations registered at the Charity Commission. The UK has three different bodies that are in charge of controlling and regulating UK charities: the "Charity Commission" which registers and regulates charities in England \& Wales, the "Charity Commission for Northern Ireland" that deals with regulating charities in Northern Ireland and the "Office of the Scottish Charity Regulator (OSCR)", an independent body that deals with the control and regulation of Scottish charities. A key element that makes the charities in England \& Wales particularly "accountable" compared to the NPOs of some other countries, is that in England \& Wales the status of charity is not a legal form by which an organisation is constituted, it is a status that the organisation acquires if it can demonstrate to the regulator that it carries out its activities and uses its available resources for a "charitable purpose" and for the "public benefit". This is one of the main reasons that has led some authors to consider the United Kingdom one of the best countries in term of regulation and accountability of non-profit organizations (Irvine and Ryan, 2010).

The Charity Commission as the independent regulator for charities in England \& Wales also manages different information that charities (with some exemptions related to their size) have to submit. Table 1 below summarizes the documents charities have to submit according to their income brackets.

Table 1. Due documents for financial periods ending on or after 1 April 2009

\begin{tabular}{|c|c|c|c|c|c|c|}
\hline $\begin{array}{l}\text { Income } \\
\text { in the } \\
\text { financial } \\
\text { period } \\
\text { being } \\
\text { reported }\end{array}$ & $\begin{array}{l}\text { Update } \\
\text { Register } \\
\text { Information }\end{array}$ & $\begin{array}{l}\text { Annual } \\
\text { Return - } \\
\text { basic } \\
\text { Register } \\
\text { information }\end{array}$ & $\begin{array}{l}\text { Reporting } \\
\text { Serious } \\
\text { Incidents }\end{array}$ & $\begin{array}{l}\text { Financial } \\
\text { Information }\end{array}$ & $\begin{array}{l}\text { Summary } \\
\text { Information } \\
\text { Return }\end{array}$ & $\begin{array}{l}\text { Trustees' } \\
\text { Annual } \\
\text { Report } \\
\text { and } \\
\text { accounts }\end{array}$ \\
\hline$£ 10 \mathrm{k}$ or & Yes & - & - & - & - & No \\
\hline
\end{tabular}


Bellante G. et al.

\begin{tabular}{|l|c|c|c|c|c|c|}
\hline less & & & & & & \\
\hline $\begin{array}{l}£ 10- \\
£ 25 \mathrm{k}\end{array}$ & - & Yes & - & - & - & No \\
\hline $\begin{array}{l}£ 25 \mathrm{k}- \\
£ 500 \mathrm{k}\end{array}$ & - & Yes & Yes & - & - & Yes \\
\hline $\begin{array}{l}£ 500 \mathrm{k}- \\
£ 1 \mathrm{~m}\end{array}$ & - & Yes & Yes & Yes & - & Yes \\
\hline $\begin{array}{l}\text { Greater } \\
\text { than } \\
£ 1 \mathrm{~m}\end{array}$ & - & Yes & Yes & Yes & Yes & Yes \\
\hline
\end{tabular}

Source: Charity Commission website

Each charity must give some information to the Charity Commission, and the level and complexity of the information depends on its income.

In addition to the mandatory reporting requirements, charities can also provide further voluntary information with different tools and mechanisms such as institutional websites; social networks (blogs, fora, facebook, twitter, etc.); and reports with information about mission, strategy, human resources, and social results. The use of these tools of voluntary disclosure can increase the organisation's ability to collect resources making it still more accountable. For example, the results of a study conducted by Saxton et al (2014) "indicate a positive relationship between the level of charitable contributions and the amount of disclosure provided by an organization on its website" (Saxton et al, 2014, p. 127). Greenberg and Macaulay (2009) suggest that "NPOs should be leaders in using social technologies to grow and strengthen their networks" (Greenberg and Macaulay, 2009, p. 74). Waters et al. (2009) affirm that with the use of social networks, NPOs can reach different categories of stakeholders. Another aspect of accountability could be related to the disclosure of information about volunteers' contributions. Indeed, an effective management of volunteers is crucial for non-profit organisations (often entirely or very substantially based on volunteers' work), and therefore the identification of some good practices for volunteer management is suggested by several authors. The regular collection of information on volunteer involvement, the annual measurement of volunteer impact, and the supervision and communication with volunteers are some of the recommended practices identified by Hager and Brudney, (2004). Cuskelly et al. (2006) find that the use of planning practices such as providing roles or job descriptions for individual volunteers and maintaining a database of volunteers' skills, qualifications and experience are associated with fewer perceived problems in the retention of volunteers generally. Cnaan and Cascio's findings suggest that "careful screening and use of symbolic rewards are significant in explaining variation in volunteer satisfaction, hours volunteered per month (commitment), and length of service (tenure)" (Cnaan and Cascio, 1998 , p. 1). Many other authors paid attention to the theme of volunteer management exploring issues and trying to identify useful good practices for managers of NPOs (Brudney and Meijs, 2014; Cordery et al., 2013; Hager and Brudney, 2011; HaskiLeventhal and Meijs, 2011; Machin and Paine, 2008). For example, the use of a strategic plan is considered to be a good practice for NPOs since it represents a useful tool for organisations in designing their futures, setting their goals and deciding on the strategies, actions and resources to achieve them. Another positive use of this tool is to allow the organizsations to define clearly their strategic aims in order to measure their performance. Specifically, Kaplan (2001) suggests that having a clear strategy statement is necessary to any performance measurement, proposing the use of the Balance 
Scorecard as a useful tool for NPOs to "bridge the gap between vague mission and strategy statements and day-to-day operational actions" (Kaplan, 2001, p. 369) facilitating "a process by which an organization can achieve strategic focus, avoiding the pathology of attempting to be everything to everyone" (Kaplan, 2001, p. 369). The Charity Commission recommends that trustees of larger organisations "take responsibility for setting the charity's strategic aims and direction, and agreeing appropriate future plans" (Charity Commission Guidance, 2015, p. 11). Green and Griesinger (1996) find that the "boards of effective organizations tended to be more fully involved in policy formation, strategic planning, program review, board development, resource development, financial planning and control, and dispute resolution than were boards of less effective organizations" (Green and Griesinger, 1996, p. 398]. Other authors investigated the relationships between strategic planning and organisational performance in non-profit contexts. Griggs (2003) finds that "strategic planning intensity does have an effect on organisational performance in disability-based organisations" (Griggs, 2003, p. 212) and in her study of 240 organisations, Siciliano (1996) finds that "those organizations that used a formal approach to strategic planning had higher levels of financial and social performance than those with less formal processes" (Siciliano, 1996, p. 387), regardless of the organisation's size. Following these results, we argue that the publication of information on volunteers, the declared use of a strategic plan and the presence of social networks are tools of voluntary disclosure that strengthen the positive effects of the mechanisms of mandatory accountability. In essence, the potential for agency problems is substantially diminished if there are additional mechanisms which allow stakeholders (users, donors and the regulator) to hold the organisation to account. We predict a positive impact of the use of these tools on the organisational performance:

H3: The introduction of tools of voluntary disclosure has a positive impact on the organisational performance (measured as its ability in collecting resources, i.e. total revenues), increasing the strength of the mechanisms of mandatory accountability.

Specifically, we propose that:

H3(a): The publication of information on volunteers on the charity's website or reports has a positive impact on the organisational performance (total revenues).

H3(b): The use of social networks (fora, blogs, facebook, twitter, etc.) has a positive impact on the organisational performance (total revenues).

H3(c): The declared use of a strategic plan has a positive impact on the organisational performance (total revenues).

\section{Methods and sample}

Our analysis was conducted on a sample of 200 charities selected randomly from the Register of the Charity Commission. We selected the charities that met the following requirements: (a) presence of an institutional website; (b) presence of an annual report or a financial statement (financial data of 2013) published on the Charity Commission's 
Bellante G. et al.

Register. The year considered for the financial data collection is 2013. The analysis, based on econometric techniques, consists of two phases. In the first one we aim to verify the hypotheses about the relationship between the two characteristics of governance (CEO duality and board size) and the organisational performance (H1 and H2). Next, we analyse if and how our model (and the relationships found) changes if the charity increases its level of accountability using voluntary disclosure tools (H3, H3(a), H3(b), $\mathrm{H} 3(\mathrm{c}))$.

\section{Variables and models}

Our dependent variable, organisational performance, is operationalised as the natural logarithm of total revenues in the fiscal year 2013 (In_revenues). Financial indicators are often used to measure organisational performance in studies of non-profit organisations (Harris, 2014), and the ability to collect resources is an important organisational goal (Epstein and McFarlane, 2011). Therefore, similar to Grasse, Davis and Ihrke (2014) we consider revenues to be a good measure of performance in non-profit organizations.

Our control variable is the natural logarithm of the charity's number of human resources, calculated as the sum of the number of paid staff and volunteers (ln_hr). This is an organisational-level characteristic which allows us to control for size effects.

Our independent variables are, in the first phase:

- CEO duality (the CEO and the chair/president of the board are the same person); it is a dummy variable coded 1 if there is duality and 0 if there is not (ceo_duality);

- board size, calculated as the number of trustees of the board (board_size).

The independent variables considered in the second phase are:

- information on volunteers, published on the charities' websites or reports. It is a dummy variable coded 1 if there is information on volunteers published (on the charity's website or reports) and 0 if there is not (volunteers_info);

- use of social networks. It is a dummy variable coded 1 if the charity uses social networks and 0 if it does not (soc_network);

- declared use of a strategic plan. It is a dummy variable coded 1 if the charity has a strategic plan and declares to use it and 0 if it does not (strategic_plan).

We use the natural logarithm of our dependent (total revenues in 2013) and control (number of human resources) variables to control the variability and heterogeneity of these quantitative variables (see table 2). When examining the variable "board_size", the data collected show that the nonprofit board is almost never "oversized", indeed $90.50 \%$ of the charities in the sample have a board size with less than 15 members (see table 3 ).

Table 2. Summary statistics of quantitative variables

\begin{tabular}{llllll}
\hline Variable & Obs & Mean & Std.Dev. & Min & Max \\
\hline Revenues $(\mathfrak{£})$ & 200 & $2,111,272$ & $7,249,464$ & 25,190 & $73,355,000$ \\
hr & 167 & 174.1377 & 620.4821 & 4 & 5,019 \\
Board_size & 200 & 8.95 & 4.24708 & 2 & 31 \\
\hline
\end{tabular}

Table 3. Board size 
Accountability, Governance and Performance in UK charities

\begin{tabular}{lll}
\hline Number of board members & freq. & Percent. \\
\hline $\mathbf{2 - 1 4}$ & 181 & 90.50 \\
$\mathbf{1 5 - 3 1}$ & 19 & 9.50 \\
Total & $\mathbf{2 0 0}$ & $\mathbf{1 0 0 . 0 0}$ \\
\hline
\end{tabular}

\section{$5 \quad$ Result and discussion}

The analysis was conducted using multiple regression models $(\log -\log )$, first in a context of a medium-high level of mandatory accountability and following that, when the charities increase their level of accountability using tools of voluntary disclosure. Our sample is composed of 200 organisations but the analysis (regression models) was conducted on 167 units because of missing values related to the control variable "human resources". Results are reported in table 4. The constant was omitted from our models because it was not significant. Hypothesis 1 predicts that CEO duality has a positive impact on organisational performance (measured as its ability in collecting resources, i.e. total revenues), in a context characterized by a medium-high level of accountability; while according to hypothesis 2 , increasing board size has a positive impact on the organisational performance, in a context characterized by a medium-high level of accountability that can mitigate the possible negative effects considered by the agencytheoretic literature.

Table 4. Impact of board size and $\mathrm{CEO}$ duality on the organisational performance in charities characterized by a medium-high level of mandatory accountability and the effects of the use of voluntary disclosure tools

\begin{tabular}{|c|c|c|c|c|}
\hline VARIABLES & $\begin{array}{c}\text { (1) } \\
\text { ln_revenues }\end{array}$ & $\begin{array}{c}(2) \\
\text { ln_revenues }\end{array}$ & $\begin{array}{c}(3) \\
\text { ln_revenues }\end{array}$ & $\begin{array}{c}(4) \\
\text { ln_revenues }\end{array}$ \\
\hline ln_hr & $\begin{array}{c}2.354 * * * \\
(0.147)\end{array}$ & $\begin{array}{c}2.193 * * * \\
(0.174)\end{array}$ & $\begin{array}{c}1.903 * * * \\
(0.172)\end{array}$ & $\begin{array}{c}1.900 * * * \\
(0.174)\end{array}$ \\
\hline board_size & $\begin{array}{c}0.350 * * * \\
(0.0584)\end{array}$ & $\begin{array}{c}0.359^{* * * *} \\
(0.0583)\end{array}$ & $\begin{array}{c}0.278 * * * \\
(0.0564)\end{array}$ & $\begin{array}{c}0.278 * * * \\
(0.0567)\end{array}$ \\
\hline ceo_duality & $\begin{array}{c}2.184 * * * \\
(0.695)\end{array}$ & $\begin{array}{c}2.121 * * * \\
(0.693)\end{array}$ & $\begin{array}{c}1.959 * * * \\
(0.645)\end{array}$ & $\begin{array}{c}1.977 * * * \\
(0.659)\end{array}$ \\
\hline volunteers_info & & $\begin{array}{l}0.939^{*} \\
(0.558)\end{array}$ & $\begin{array}{c}0.417 \\
(0.528)\end{array}$ & $\begin{array}{c}0.411 \\
(0.532)\end{array}$ \\
\hline $\begin{array}{l}\text { soc_network } \\
\text { strategic_plan }\end{array}$ & & & $\begin{array}{c}2.912 * * * \\
(0.566)\end{array}$ & $\begin{array}{c}2.901 * * * \\
(0.573) \\
0.0834 \\
(0.572)\end{array}$ \\
\hline $\begin{array}{l}\text { Observations } \\
\text { R-squared }\end{array}$ & $\begin{array}{c}167 \\
0.932\end{array}$ & $\begin{array}{c}167 \\
0.934\end{array}$ & $\begin{array}{c}167 \\
0.943\end{array}$ & $\begin{array}{c}167 \\
0.943\end{array}$ \\
\hline
\end{tabular}


The first phase of our analysis (Model 1) aims to verify hypotheses 1 (H1) and 2 $(\mathrm{H} 2)$. The results show that both of our hypotheses are supported. Positive and significant associations are found between board size and the total revenues $(\mathrm{p}<0.001)$ and between CEO duality and the total revenues $(\mathrm{p}<0.001)$. These results are consistent with the argument that in a context characterized by a medium-high level of accountability (as in England \& Wales), the accountability tools of NPOs reinforce the strength of the board of directors in monitoring the CEO's activities, and blunt one side of the double edged sword related to CEO power (Finkelstein and D'Aveni, 1994). Our control variable, the number of human resources (ln_hr), is highly correlated with the financial performance of the organisations. The second step of our analysis (Models 2, 3,4) checks if and how the relations found in the first phase change if the charity introduces some tools of "voluntary disclosure". The relations found in the first phase are confirmed also in the second one. In addition, we predicted positive relations between the three variables considered (volunteers_info, soc_network, strategic_plan) and the ability of the organization to collect resources (ln_revenues). Our hypothesis is partially confirmed: the publication of information about the volunteers has a weak positive and significant $(p<0.1)$ effect on the ability of the charity to collect resources (see model 2) but the significance of this relation disappears in the following analysis (see models 3 and 4), while the declared use of a strategic plan seems not to influence the total revenues (ln_revenues). On the contrary, the use of social networks has a strong significant $(\mathrm{p}<0.001)$ and positive impact on this type of organisational performance. This result can be explained by the typology of the variable itself, in particular the use of social networks can be seen as a tool that allows beneficiaries, workers, lenders, donors and the general public to interact with the charity. Thanks to the use of social networks, such as facebook, twitter, blogs, and so on, people can give their opinion about the charity's activities, can share their experiences, give advice, and participate in the charity's mission. These results are consistent with the study of Muralidharan et al. (2011) who analysed Facebook and Twitter usage of non-profits during earthquake missions. They found that "Nonprofits seem to encourage a steady stream of visitors to Facebook and Twitter forming an important means of increasing donations and active participation than media organizations" (Muralidharan et al., 2011, p. 177). Also Saxton and Wang (2014) demonstrated in their work that social networks can facilitate new ways of raising and giving money in charitable organisations. It is, however, important to highlight that maybe the inverse of this relationship can also be true. For example, Greenberg and Macaulay (2009) affirm that "Even though hardware and software expenses continue to decline in relative terms, the costs of maintaining and upgrading an organisation's technological infrastructure can be prohibitive, particularly for smaller organizations" (Greenberg and Macaulay, 2009, p. 67). This could mean that it is the level of revenues of an organisation that influences its use of social networks rather than the other way around. In order to analyse more in depth the qualitative variables considered in this study, we use a different methodology of analysis, namely logistic regression. This different technique allows us to verify the level of association between pairs of variables: (a) CEO duality - total revenues; (b) information on volunteers - total revenues; (c) the use of social networks - total revenues; (d) the declared use of a strategic plan - total revenues. In order to manage and to interpret easily the variable "total revenues", we classified it into four groups by means of the quartiles of the distribution [Class 1: total revenues < £ 105217; Class 2: $£ 105218<$ total revenues < $£ 287548$; Class 3: $£ 287549<$ total revenues <£948138; Class 4: total revenues $>£ 948139]$. The chi-square test on the 
association tables between each pair of variables is significant for the following associations: (a) ceo_duality and revenues_classes; (c) soc_network and revenues_classes; (d) strategic_plan and revenues_classes. This motivated us to estimate a logistic regression for the above pairs of variables. The results are summarised in table 5 below:

Table 5: Logistic Regressions

(a) Dependent variable: ceo_duality

Independent variable: revenues_classes

\begin{tabular}{lllllll}
\hline & $\begin{array}{l}\text { Odds } \\
\text { Ratio }\end{array}$ & Std. Err. & $\mathbf{z}$ & P(z) & \multicolumn{2}{l}{ (95\% Conf. Interval) } \\
\hline Ceo_duality & .4407105 & .0760446 & -4.75 & 0.000 & .3142524 & .6180567 \\
\hline
\end{tabular}

(b) Dependent variable: soc_network

Independent variable: revenues_classes

\begin{tabular}{lllllll}
\hline & $\begin{array}{l}\text { Odds } \\
\text { Ratio }\end{array}$ & Std. Err. & $\mathbf{z}$ & \multicolumn{2}{c}{$\mathbf{P}(\mathbf{z})$} & \multicolumn{2}{c}{ (95\% Conf. Interval) } \\
\hline Soc_network & 1.460565 & .2209521 & 2.50 & 0.012 & 1.085806 & 1.964669 \\
\hline
\end{tabular}

(c) Dependent variable: strategic_plan

Independent variable: revenues_classes

\begin{tabular}{lllllll}
\hline & $\begin{array}{l}\text { Odds } \\
\text { Ratio }\end{array}$ & Std. Err. & $\mathbf{z}$ & P(z) & \multicolumn{2}{c}{ (95\% Conf. Interval) } \\
\hline Strategic_plan & 2.174183 & .3551047 & 4.76 & 0.000 & 1.578597 & 2.994478 \\
\hline
\end{tabular}

The results of table 5 can be interpreted as follows: the level of revenues of organisations is associated negatively with the probability to have CEO duality $(-56 \%)$; positively with the probability to have a social network $(+46 \%)$; and positively with the probability that the charity uses and declares to make a strategic plan $(+117 \%)$. The results as shown in table 5 indicate that the presence of CEO duality is negatively associated with the level of revenues of a charity. If we consider the level of revenues as a measure of the charity's size, we can affirm that in larger organisations the probability to have duality is lower than in smaller ones. The results of the logistic regression show also that the use of social networks is positively associated with the organisation's size, expressed in terms of total revenues. This result confirms the statement of Greenberg and Macaulay (2009) according to which for smaller organizations the costs related to maintaining and upgrading their social networks can be too high, that is the level of 


\section{Bellante G. et al.}

revenues of an organization can influence its use of social networks. Finally, the findings in table 5 show that the declared use of a strategic plan represents a variable that, even if it does not seem to influence the revenues in our previous regression models, is strongly associated with the classes of revenues of charities, and specifically the declared use of an instrument of strategic planning characterises the largest organisations (in terms of total revenues). This result is consistent with previous studies in the literature. Stone et al. (1999) in their review of strategic management in non-profit organisations found that "Many nonprofits have not adopted formal strategic planning. For those that do adopt formal strategic planning, primary determinants are organization size, characteristics of board and of management, prior agreement on organizational goals, and funder requirements to plan" (Stone et. al, 1999, p. 383). Thus, the organisation's size seems to be a determinant for the decision about the adoption of a strategic plan. This result suggests that the recommended practice of the Charity Commission about the importance for larger charities to set the charity's strategic aims and direction, and to agree appropriate future plans is widely followed by charities in England \& Wales.

In order to conclude our exploratory analysis on the relationships between the characteristics of governance and accountability, we conducted a multiple correspondence analysis and we found that the presence of CEO duality is strongly associated with smaller charities, both the presence of social networks and the declared use of a strategic plan are associated with larger organizations, while the publication of information about volunteers characterises mainly medium-to-large sized organisations. We considered the classes of revenues, classified in four groups by means of the quartiles of the distribution, as a measure of the organisation's size. Results shown in the following graph are significant, indeed, the first two dimensions explain more than the $84 \%$ of the phenomenon studied.

Figure 1: Multiple correspondence analysis (MCA) 


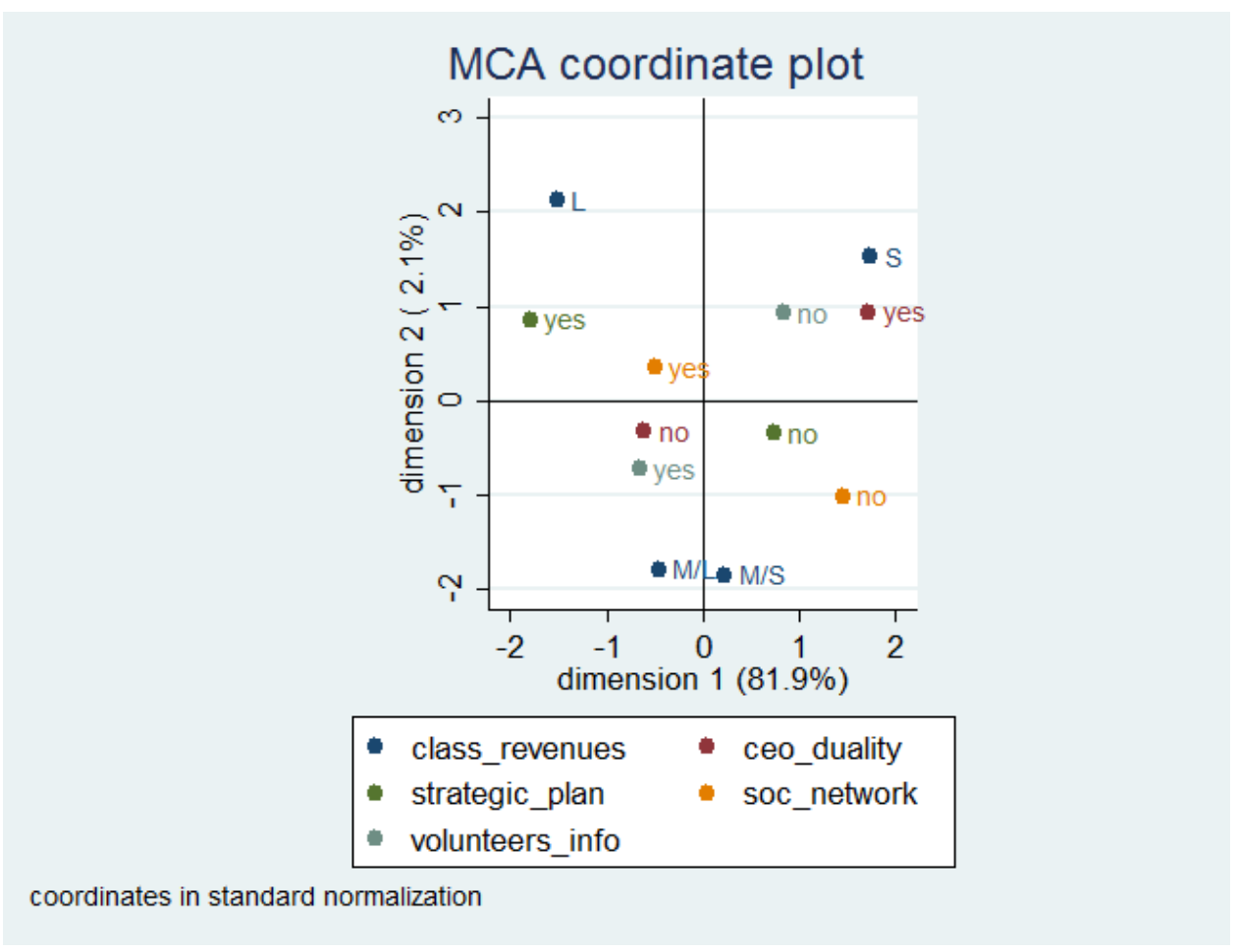

Note: "S" means "Small charities" with total revenues less than $£ 105.217$; "M/S" means "Medium/Small charities" with total revenues between $£ 105.218$ and $£ 287.548$; "M/L" means "Medium/Large charities" with total revenues between $£ 287.549$ and $£ 948.138$; and "L" means "Large charities" with total revenues higher than $£ 948139$.

\section{Conclusions}

The aim of this paper was to understand how mechanisms of accountability can indirectly affect the organisational performance, increasing or mitigating, respectively, the positive or negative effects in the relationship between board characteristics (board size and CEO duality) and the ability of the non-profit organisation to collect resources. We predicted that in a context characterised by a medium-high level of accountability, the negative effect of CEO duality and larger board size as hypothesised by agency theory is not likely to occur since the accountability tools and mechanisms are a substitute for board monitoring. To test our hypothesis, we referred to the UK third sector context, in particular, England \& Wales, because this regulator model represents an example of medium-high level of accountability required of charities. We conducted our analysis on a sample of 200 charities extracted randomly from the Charity Commission Register, and we found support for all our hypotheses; both CEO duality and the board size have a significant positive influence on the ability of the charity to collect resources (total revenues). These results are consistent with prior literature and specifically, with the proponents of the stewardship theory, resource dependence theory and stakeholder theory 


\section{Bellante G. et al.}

(i.e. Bai, 2013; Davis et al., 1997; Donaldson and Davis, 1991; Cornforth, 2003; Hyndman and McDonnell, 2009). A consecutive phase of our study aimed to verify if and how the relations found in the previous step change if the charity increases its level of accountability, complementing tools of voluntary disclosure with those mandatory ones required by the Charity Commission. The relationships found in the first phase were confirmed also in the second one. However, of the three tools of voluntary disclosure that we considered, the use of social networks is the variable with the strongest positive and significant effect; these results confirm the hypotheses and results of Greenberg and Macaulay, (2009); Waters et al. (2009); and Saxton and Wang (2014). However, the publication of information on volunteers has a weak significant and positive effect on total revenues, while the declared use of a strategic plan is not significant.

This study has several important implications both for the regulators of non-profit organisations in different countries and for the governing bodies of the non-profit organizations themselves. Specifically, the results of this study show that if non-profit organisations work in a context characterized by a medium-high level of accountability, such as in England \& Wales, CEO duality can indeed be beneficial for organisational performance. Both boards and regulators should therefore pay closer attention to context and avoid 'one-size-fits all' prescriptions. This study also shows that if the NPO provides voluntarily information about its activities through the use of social networks, its ability to collect resources increases. If the organisations provide the public with the opportunity to interact with them, to give opinions, to participate in their activities, the stakeholders (and the potential donors) would probably feel more involved and confident, and therefore more likely to be motivated to contribute with donations to support the organisation's mission. Finally, the results of a logistic regression, used to explore how some characteristics of charities related to their level of revenues, showed that large charities are more likely to make use of social networks and declare the use of a strategic plan, while it is less probable to encounter CEO duality here. These results can help the reader to understand how some qualitative characteristics of the NPOs are associated with the organisation's size. Findings of the logistic regression are also confirmed by the multiple correspondence analysis that highlights the associations between board characteristics and voluntary disclosure considered in this study and one variable of the organisation's dimension, the "total revenues" classified into four groups. Further research could test for these relationships in other medium-to-high accountability NPO contexts (such as Canada and USA); or in countries characterized by a lower level of accountability (such as Italy and Norway) to verify if and how these relationships change. Furthermore, a possible future improvement to the study could be the deeper analysis of the large amount of documents published by the organizations (annual reports, social reports, strategic plans, etc.) towards, for example, a content analysis. We are aware that the financial measure of total revenues could be considered as not completely comprehensive of the ability of the charity to collect resources, because there are some resources that are not evaluated or evaluable; in addition it represents only one single aspect of the overall performance. Furthermore, the capacity of NPOs to collect resources could be affected also by other aspects such as the belonging of the organisation to particular networks; the NPO's reputation and its field of activity. These aspects could be analysed deeper in future research. Lastly, the different basis of financial accounting used by the organizations, cash based (12 charities) and accrual based (188 charities), can potentially limit comparability. 
Accountability, Governance and Performance in UK charities

\section{References}

Adams, R., Hermalin, B. E. and Weisbach, M.S. (2008) 'The role of boards of directors in corporate governance: A conceptual framework and survey', NBER Working Paper No. 14486

Aguilera, R., Filatotchev, I., Gospel, H. and Jackson, G. (2008) 'An organizational approach to comparative corporate governance: Costs, contingencies and complementarities', Organization Science, Vol. 19 No. 3, pp.475-492

Anheier, H. K. (2005) Nonprofit organizations: theory, management, policy, Routledge

Bai, G. (2013) 'How do board size and occupational background of directors influence social performance in for-profit and non-profit organizations? Evidence from California hospitals', Journal of Business Ethics, Vol. 118 No.1, pp.171-187

Baliga, B.R., Moyer, R.C. and Rao, R.S. (1996) 'CEO Duality and Firm Performance: What's the Fuss?', Strategic Management Journal, Vol. 17, pp. 41-53

Behn, B.K., DeVries, D.D., and Lin, J. (2010) 'The determinants of transparency in nonprofit organizations: An exploratory study', Advances in Accounting, incorporating Advances in International Accounting, Vol. 26 No. 1, pp. 6-12

Boyd, B.K. (1995) 'CEO duality and firm performance: A contingency model', Strategic Management Journal, Vol.16 No.4, pp.301-312

Bradshaw, P., Hayday, B., Armstrong, R., Levesque, J. and Rykert, L. (1998) 'Nonprofit Governance Models: Problems and Prospects'. ARNOVA Conference Seattle Washington

Brickley, J.A., Coles, J.L, Jarrell, G. (1997) 'Leadership structure: Separating the CEO and Chairman of the Board', Journal of Corporate Finance, Vol.3 No.3, pp.189-220

Bridle, D. (2012) 'Charities hit by funding switch to business', The Guardian, 20th March 2012. [online] https://www.theguardian.com/society/2012/mar/20/charities-hitstate-funding-switch (Accessed 17 October 2016)

Brudney, J.L., and Meijs, L.C.P.M. (2014) 'Models of Volunteer Management: Professional Volunteer Program Management in Social Work', Human Service Organizations: Management, Leadership \& Governance, Vol. 38 No.3, pp.297-309

Callen, J.L., Klein, A., and Tinkelman, D. (2003) 'Board Composition, Committees, and Organizational Efficiency: The Case of Nonprofits', Nonprofit and Voluntary Sector Quarterly, Vol.32 No.4, pp.493-520

Charity Commission (2015), The essential trustee: what you need to know, what you need to do (CC3), [online] https://www.gov.uk/government/uploads/system/uploads/attachment_data/file/509664 lcc3 lowink.pdf (Accessed 17 October 2016)

Cnaan, R.A., and Cascio, T.A. (1998) 'Performance and Commitment. Issues in Management of Volunteers in Human Services Organizations' Journal of Social Service Research, Vol.24 No.3-4, pp.1-37

Cnaan, R.A. (1996) 'Commentary' Nonprofit Management \& Leadership, Vol.7 No.2, pp. 221-228

Connolly, C., Hyndman, N., and McConville, D. (2013) 'UK charity accounting: An exercise in widening stakeholder engagement' The British Accounting Review, Vol.45 No.1, pp.58-69 
Bellante G. et al.

Cordery C. J., Proctor-Thomson S. B. and Smith K. A. (2013) 'Towards communicating the value of volunteers: lessons from the field', Public Money \& Management, Vol.33 No.1, pp.47-54

Cuskelly, G., Taylor, T., Hoye, R. and Darcy, S. (2006) 'Volunteer Management Practices and Volunteer Retention: A Human Resource Management Approach'. Sport Management Review, Vol.9, pp.141-163

Cornforth, C. (2003) The Governance of Public and Non-Profit Organizations. What do boards do? Routledge

Cornforth, C. (2001) 'What Makes Boards Effective? An examination of the relationships between board inputs, structures, processes and effectiveness in non-profit organisations', Corporate Governance: An International Review, Vol.9 No.3, pp.217227

Dalton, D.R. and Dalton, C.M. (2011) 'Integration of Micro and Macro Studies in Governance Research: CEO Duality, Board Composition, and Financial Performance', Journal of Management, Vol.37 No.2, pp.404-411

Dalton, D.R., Daily, C.M., Ellstrand, A.E. and Johnson, J.L. (1998) 'Meta-Analytic reviews of board composition, leadesrhip structure and Financial Performance', Strategic Management Journal, Vol.19 No.3, pp.269-290

Dalton, D., Daily, C., Johnson, J. and Ellstrand, A. (1999) 'Number of directors and financial performance: A meta-analysis', Academy of Management Journal, Vol.42 No.6, pp.674-686

Davis, J., Schoorman, F. and Donaldson, L. (1997) 'Toward a stewardship theory of management', Academy of Management Review, Vol.22 No.1, pp.20-47

Donaldson, L. and Davis, J.H. (1991) 'Stewardship theory or agency theory: CEO governance and shareholder returns', Australian Journal of Management, Vol.16 No.1, pp.49-64

Ebrahim, A. (2010) 'The Many Faces of Nonprofit Accountability'. Harvard Business School Working Paper, No.10-069, pp.1-32 [online] http://www.hbs.edu/faculty/Publication\%20Files/10-069.pdf (Accessed 17 October 2016)

Elsayed, K. (2007) 'Does CEO duality really affect corporate performance?', Corporate Governance, Vol.15 No.6, pp.1203-1214

Epstein, M.J. and McFarlan, F.W. (2011) 'Nonprofit vs. For-Profit Boards: Critical Differences'. Strategic Finance, Vol.92 No.9, pp.28-35

Fama, E. F. and Jensen, M. C. (1983) 'Separation of ownership and control', Journal of Law and Economics, Vol.26 No.2, pp. 301-325

Finkelstein, S. and D' Aveni, R. A. (1994) 'CEO Duality as a Double-Edged Sword: How Boards of Directors Balance Entrenchment Avoidance and Unity of Command', The Academy of Management Journal, Vol.37 No.5, pp.1079-1108

Gibelman, M. and Gelman, S. R. (2001) 'Very Public Scandals: Nongovernmental Organizations in Trouble'. Voluntas: International Journal of Voluntary and Nonprofit Organizations, Vol.12 No.1, pp.49-66

Grant Thornton (2013) 'The Science of Good Governance: Towards Charity Best Practice', Charity Governance Review 2013, [online] http://www.grantthornton.co.uk/Global/Publication_pdf/Charity-Governance-Review-2013.pdf (Accessed 17 October 2016)

Grasse, N., Davis, T. and Ihrke, D. (2014) 'Understanding the Compensation of Nonprofit Executive Directors. Examining the Influence of Performance and 
Organizational Characteristics', Nonprofit Management \& Leadership, Vol.24 No.3, pp.377-398

Green, J.C. and Griesinger, D.W. (1996) 'Board Performance and Organizational Effectiveness in Nonprofit Social Services Organizations', Nonprofit Management \& Leadership, Vol.6 No.4, pp.381-402

Greenberg, J. and Macaulay, M. (2009) 'NPO 2.0? Exploring the Web Presence of Environmental Nonprofit Organizations in Canada', Global Media Journal Canadian Edition, Vol.2 No.1, pp.63-88

Griggs, H.E. (2003) 'Corporatisation of the Not-For-Profit Sector: Strategic planning and organisational performance in disability-based organisations', International Journal of Disability, Development and Education, Vol.50 No.2, pp.197-220

Hager, M.A. and Brudney, J.L. (2011) 'Problems Recruiting Volunteers. Nature versus Nurture', Nonprofit Management \& Leadership, Vol.22 No.2, pp.137-157

Hager, M.A. and Brudney, J. L. (2004) 'Volunteer Management. Practices and Retention of Volunteers'. Volunteer Management Capacity Study Series, The Urban Institute [online] http://www.volunteertoday.com/PDF/upsreportVolMgmt.pdf (Accessed 17 October 2016)

Hambrick, D., v.Werder and A., Zajac, E. (2008) 'New directions in corporate governance research', Organization Science, Vol.19 No.3, pp.381-385

Harris, E. (2014) 'The Impact of Board Diversity and Expertise on Nonprofit Performance', Nonprofit Management \& Leadership, Vol.25 No.2, pp.113-130

Haski-Leventhal and D., Meijs, L.C.P.M. (2011) 'The volunteer matrix: positioning of volunteer organizations', International Journal of Nonprofit and Voluntary Sector Marketing, Vol.16, pp.127-137

Hillman, A., and Dalziel, T. (2003) 'Boards of directors and firm performance: Integrating agency and resource dependence perspectives', Academy of Management Review, Vol.28 No.3, pp.383-396

House of Commons (2016) The 2015 charity fundraising controversy: lessons for trustees, the Charity Commission and regulators. Third Report of Session 2015-2016, House of Commons, Public Administration and Constitutional Affairs Committee, London: The Stationary Office, [online] http://www.publications.parliament.uk/pa/cm201516/cmselect/cmpubadm/431/431.pd f (Accessed 17 October 2016)

Hyndman, J. and McDonnell, P. (2009) 'Governance and charities: An exploration of key themes and the development of a research agenda', Financial Accountability \& Management, Vol.25 No.1, pp.5-31

Irvine, H. and Ryan, C. (2010) An International Comparison of Not-for-Profit Accounting Regulation? http://apira2010.econ.usyd.edu.au/conference_proceedings/APIRA-2010-092-IrvineNot-for-profit-accounting-regulation.pdf (Accessed 17 October 2016)

Jenkin, B. (2016) 'Charity trustees are to blame for the fundraising scandal', The Guardian, 28th January 2016 [online] https://www.theguardian.com/voluntary-sectornetwork/2016/jan/28/trustees-responsibility-charity-fundraising-scandal (Accessed 17 October 2016)

Jensen, M.C. (1993) 'The Modern Industrial Revolution, Exit, and the Failure of Internal Control Systems'. The Journal of Finance, Vol.48 No.3, pp.831-880 
Bellante G. et al.

Judge, W. and Zeithaml, C. (1992) 'Institutional and strategic choice perspectives on board involvement in the strategic decision process', Academy of Management Journal, Vol.35 No.4, pp.766-794

Kaplan, R.S. (2001) 'Strategic Performance Measurement and Management in Nonprofit Organizations'. Nonprofit Management \& Leadership, Vol.11 No.3, pp.353-370

Keating, E. K. and Frumkin, P. (2003) 'Reengineering Nonprofit Financial Accountability: Toward a More Reliable Foundation for Regulation', Public Administration Review, Vol.63 No.1, pp.3-15

Krause, R., Semadeni, M. and Cannella, A. (2014) 'CEO duality: A review and research agenda', Journal of Management, Vol.40 No.1, pp.256-286

Lipton, M. and Lorsch, J. (1992) 'A modest proposal for improved corporate governance', The Business Lawyer, Vol.48 No.1, pp.59-77

Lorsch, J. and MacIver, E. (1989) Pawns or Potentates: The Reality of America's Corporate Boards, Harvard Business School Press

Machin, J. and Paine, A.E. (2008) Management matters: a national survey of volunteer management capacity. Institute for Volunteering Research [online] http://citeseerx.ist.psu.edu/viewdoc/download?doi=10.1.1.463.9743\&rep=rep1\&type =pdf (Accessed 17 October 2016)

Miller-Millesen, J.L. (2003) 'Understanding the Behavior of Nonprofit Boards of Directors: A Theory-Based Approach', Nonprofit and Voluntary Sector Quarterly, Vo.32 No.4, pp.521-547

Misangyi, V. and Acharya, A. (2014) 'Substitutes or complements? A configurational examination of corporate governance mechanisms', Academy of Management Journal, Vol.57 No.6, pp.1681-1705

Muralidharan, S., Rasmussen, L., Patterson, D. and Shin, J.H. (2011) 'Hope for Haiti: An analysis of Facebook and Twitter usage during the earthquake relief efforts'. Public Relations Review, Vol.37 No.2, pp.175-177

NCVO (2014) Report of the Inquiry into Charity Senior Executive Pay and Guidance for Trustees on Setting Remuneration, National Council for Voluntary Organisations, London [online] https://www.ncvo.org.uk/images/documents/about us/our-financesand-pay/Executive Pay_Report.pdf (Accessed 17 October 2016)

Peni, E. (2014) 'CEO and Chairperson characteristics and firm performance'. Journal of Management and Governance, Vol.18 No.1, pp.185-205

Pfeffer, J. and Salancik, G. (1978) The External Control of Organizations: A Resource Dependence Perspective, Stanford University Press, Stanford

Rechner, P.L. and Dalton, R.D. (1991) 'Research notes and communications. Ceo duality and organizational performance: a longitudinal analysis', Strategic Management Journal, Vol.12 No.2, pp.155-160

Saxton, G. D., Neely, D. G. and Guo, C. (2014) 'Web disclosure and the market for charitable contributions', Journal of Accounting and Public Policy, Vol.33 No.2, pp.127-144

Saxton, G. D. and Wang, L. (2014) 'The Social Network Effect: The Determinants of Giving Through Social Media', Nonprofit and Voluntary Sector Quarterly, Vol.43, pp.850-868

Schedler, A. (1999) "Conceptualizing Accountability" in The Self-Restraining State: Power and Accountability in New Democracies. Lynne Rienner Publishers

Schiehll, E., Ahmadjian, C. and Filatotchev, I. (2014) 'National governance bundles perspectives: Understanding the diversity of corporate governance practices at the 
firm and country levels', Corporate Governance: An International Review, Vol.22 No.3, pp.179-184

Seymour, T., Gilbert, D. and Kolsaker, A. (2006) 'Aspects of market orientation of English and Welsh charities', Journal of Nonprofit and Public Sector Marketing, Vol.16 No.1-2, pp.151-169

Siciliano, J.I. (1996) 'The Relationship Between Formal Planning nand Performance in Nonprofit Organizations', Nonprofit Management\&Leadership, Vol.7 No.4, pp.387403

Stone, M. M., Bigelow, B. and Crittenden, W. (1999) 'Research on Strategic Management in Nonprofit Organizations: Synthesis, Analysis, and Future Directions', Administration \& Society, Vol.31 No.3, pp.378-423

Sundaramurthy, C. and Lewis, M. (2003) 'Control and collaboration: Paradoxes of governance', Academy of Management Review, Vol.28 No.3, pp.397-415

Sussex, P. (2015) 'Scandal-hit charities need a strong regulator', The Guardian, 16th September 2016 [online] https://www.theguardian.com/society/2015/sep/16/scandalhit-charities-strong-regulator-charity-commission (Accessed 17 October 2016)

Van Puyvelde, S., Caers, R., du Bois and C., Jegers, M. (2012) 'The governance of nonprofit organizations: Integrating agency theory with stakeholder and stewardship theories', Nonprofit and Voluntary Sector Quarterly, Vol.41 No.3, pp.431-451

Waters, R.D., Burnett, E., Lamm, A. and Lucas, J. (2009) 'Engaging stakeholders through social networking: How nonprofit organizations are using Facebook'. Public Relations Review, Vol.35 No.2, pp.102-106

Wang, J. and Dewhirst, H. (1992) 'Boards of directors and stakeholder orientation', Journal of Business Ethics, Vol.11 No.2, pp.115-123

Worth, M.J. (2009) Nonprofit Management. Principles and Practice, SAGE Publication 